\title{
Mynsters and Parishes: Some Evidence and Conclusions from Wiltshire
}

\author{
Jonathan Pitt
}

Fortunate historians find themselves taught or supervised by an academic who inspires and whose reputation for knowledge, scholarship and judgement proves to be justified during the experience. A desire to emulate that teacher or supervisor is likely to result and, though often remaining unrealised, may still result in small contributions to our knowledge of the past.

Whether it is fortunate to begin a programme of research at a time when the foundations of the topic are under attack is less certain. The 'minster model'1 describes a system of early medieval pastoral provision based on a network of churches which, being generally the oldest in their parishes, had responsibilities towards, and rights over, those parishes - the latter, naturally, larger at the time than parishes of the later medieval period. In accordance with their functions, typically these 'minsters' required a staff of several clergy and a landed endowment to match. Aspects of the model have been a matter of debate, fuelled by questions of terminology and by scepticism, particularly as to how early a network of mynster parishes might have existed. ${ }^{2}$ Though understandable in light of the available evidence, some of this seemed founded on

1 To set out the basics: P.H. Hase, "The Development of the Parish in Hampshire, particularly in the Eleventh and Twelfth Centuries" (PhD thesis, Univ. of Cambridge, 1975); John Blair, "Secular Minster Churches in Domesday Book," in Domesday Book: A Reassessment, ed. P.H. Sawyer (London, 1986), pp. 104-42; "Local Churches in Domesday Book and Before," in Domesday Studies: Papers Read at the Novocentenary Conference of the Royal Historical Society and the Institute of British Geographers, Winchester, 1986, ed. J.C. Holt (Woodbridge, 1987), pp. 265-78; "Minster Churches in the Landscape," in Anglo-Saxon Settlements, ed. Della Hooke (Oxford, 1988), pp. 35-58; "Introduction: From Minster to Parish Church," in Minsters and Parish Churches: The Local Church in Transition 950-1200, ed. John Blair, Oxford Univ. Committee for Archaeology Monograph 17 (Oxford, 1988), pp. 1-19.

2 My approach to terminology here is always to use the Old English mynster, given its wide contemporary application-I do not know of another vernacular word the people of the time would have used - and the simple word parish (rather than parochia), since there is no obvious reason to distinguish one kind of parish from another-except when quoting directly or indirectly from other writers. By mynster I mean a church suggested by evidence to have been of pre-Conquest origin and of more-than-ordinary status. 
arguably anachronistic doubts as to what activities 'monks' in 'monasteria' might have been expected to undertake. ${ }^{3}$ Thus it cannot reasonably be denied that:

1. the model's evidence describes the formation of the medieval parish network as a process of fragmentation, that is, a move from fewer, larger parishes to more, smaller ones;

2. to note that some of the mynsters, revealed by the evidence as superior churches in this network, were in existence by the late 7 th or early 8th centuries is not to claim that that network was unchanged during that interval;

3. the identification of mynsters of the late Saxon period is not the same as proposing that all existed 300 years earlier or were unchanged in role, character or sphere of influence during that interval, ${ }^{4}$ and

4. a study seeking to identify mynsters and the extents of their parishes has the potential to reveal much about the organisation of the landscape and the structure of its inhabitants' lives.

Wiltshire (Fig. 20.1) does not provide much data to answer questions about early ecclesiastical arrangements and functions, and this paper does not therefore seek directly to address 'the debate', but rather to summarize the available conclusions, on the grounding of the four points above, and to refine slightly

3 David Rollason and Eric Cambridge, "Debate: The Pastoral Organisation of the Anglo-Saxon Church: A Review of the 'Minster Hypothesis', and John Blair, "Debate: Ecclesiastical Organisation and Pastoral Care in Anglo-Saxon England," EME 4 (1995), 87-104, and 193-212. On the terminology as relating to the character of ecclesiastical communities: Sarah Foot, "AngloSaxon Minsters: A Review of Terminology," in Pastoral Care Before the Parish, ed. John Blair and Richard Sharpe (London, 1992), pp. 212-25, at pp. 215 and 222. Daphne Gifford in $195^{2}$ stated that the "line between early clerical and ascetic foundations was thin. "Mynster" and "monasterium" in Old English and Latin documents are the words for houses of clerks and monks alike." - "The Parish in Domesday Book," (PhD. thesis, University of London, 1952), p. 19. See also Richard Morris, Churches in the Landscape (London, 1989), pp. 128-33. Francesca Tinti, "Introduction," in Pastoral Care in Late Anglo-Saxon England, ed. Francesca Tinti (Woodbridge, 2005), pp. 1-16, at p. 13, wonders if the term monasterium should be used for religious communities of the 7 th and 8th centuries, mynster reserved for the later period: unwarranted preconceptions about the nature and roles of those establishments might still result.

4 Still, early evidence points to pastoral work being undertaken by members of early communities: Sarah Foot, "Parochial Ministry in Early Anglo-Saxon England: The Role of Monastic Communities," in The Ministry: Clerical and Lay: Papers Read at the 1988 Summer Meeting and the 1989 Winter Meeting of the Ecclesiastical History Society, ed. W.J. Sheils and Diana Wood, Studies in Church History 26 (1989), pp. 43-54, esp. pp. 46-49, 53. See also Alan Thacker, "Monks, Preaching and Pastoral Care in Early Anglo-Saxon England," in Pastoral Care Before the Parish, ed. Blair and Sharpe pp. 138-70, esp. pp. 139-43. On how mynsters might have changed, John Blair, The Church in Anglo-Saxon Society (Oxford. 2005), pp. 124-34. 


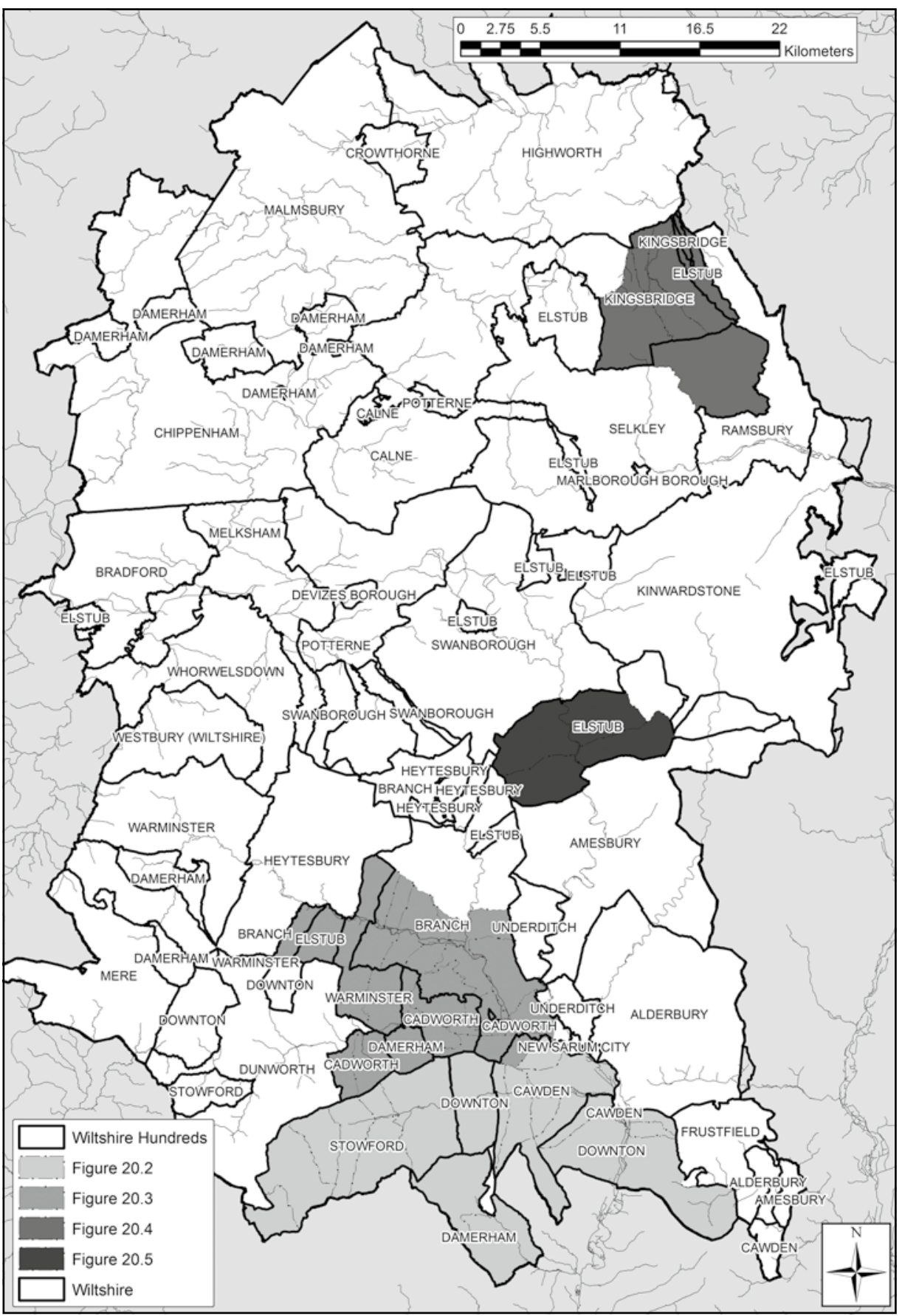

FIGURE 20.1 Wiltshire hundreds, showing the locations of hundreds discussed in the text 
the picture I have suggested previously. ${ }^{5}$ It will provide examples of the pattern and will attempt to complement some of Barbara Yorke's own interests.

Wiltshire evidence reveals a telling correspondence between a variety of clues relating to individual churches, and also between the parochial network and the administrative one in the late Saxon period. Across Wiltshire it is not uncommon for signs of a pre-Conquest religious presence to be accompanied by later evidence of a large parish and strong suggestions that parish and hundred were, in the late Saxon period, coterminous. ${ }^{6}$

An example is at Broad Chalke (Fig. 20.2) where, though no church is mentioned in Domesday Book, and there is no surviving Saxon fabric, there is a fragment of a Saxon cross-shaft, an interesting topographical situation, and late medieval evidence. The cross-shaft has been dated to the gth century, and its presence raises questions about the interpretation of such remains. Comparisons within reach of Chalke include the crosses, varied in size, type and location, recorded at an important mynster, Glastonbury, and the 8th-century Lypiatt Cross in Bisley, Gloucestershire, which, though associated with a mynster, perhaps always functioned as a boundary-marker, or a preaching cross, or both. ${ }^{7}$ Chalke's cross now stands inside a large church of cross-shaped plan on a site at least partially circular with traces of a possible enclosure-bank. On a sloping valley-side, the church site has been partly levelled off to make this enclosure.

Although no information can be found in the cartulary of Wilton Abbey which held Stowford hundred from the 1oth century, ${ }^{8}$ episcopal registers are helpful, making it clear that nearby chapels were subsidiary to the church at Broad Chalke. In 1413, Bowerchalke was still in Broad Chalke parish, an institution to the chapel reading "Bower Chalk chapel, in Chalk parish": in 1321,

5 The Wiltshire evidence is discussed more fully in J.M.A. Pitt, "Wiltshire Minster Parochiae and West Saxon Ecclesiastical Organisation" (PhD thesis, University of Southampton, 1999), and some aspects summarized in Jonathan Pitt, "Malmesbury Abbey and Late Saxon Parochial Development in Wiltshire," WANHM 96 (2003), 77-88, and "Minster Churches and Minster Territories in Wiltshire," in Boundaries in Early Medieval Britain, ed. David Griffiths, Andrew Reynolds and Sarah Semple, ASSAH 12 (Oxford, 2003), pp. 58-71.

6 For the shire's hundreds and their boundaries around the time of Domesday, F.R. Thorn, "Hundreds and Wapentakes," in The Wiltshire Domesday, ed. N.A. Hooper and F.R. Thorn, Alecto Historical Editions (1989), pp. 31-45 and Map vi accompanying-informing all comments below on the extent and boundaries of Wiltshire's hundreds.

7 John Scott, The Early History of Glastonbury: An Edition, Translation and Study of William of Malmesbury's De Antiquitate Glastonie Ecclesie (1981), pp. 78-81; Carolyn Heighway, AngloSaxon Gloucestershire (Stroud, 1987), pp. 98-99; Richard Bryant, "The Lypiatt Cross," and Michael Hare, "The Minster Status of Bisley," Transactions of the Bristol and Gloucestershire Archaeological Society 108 (1990), 33-46. and 46-49.

8 By a 10o-hide grant of $955\left(\mathrm{~S}_{582}\right)$. 


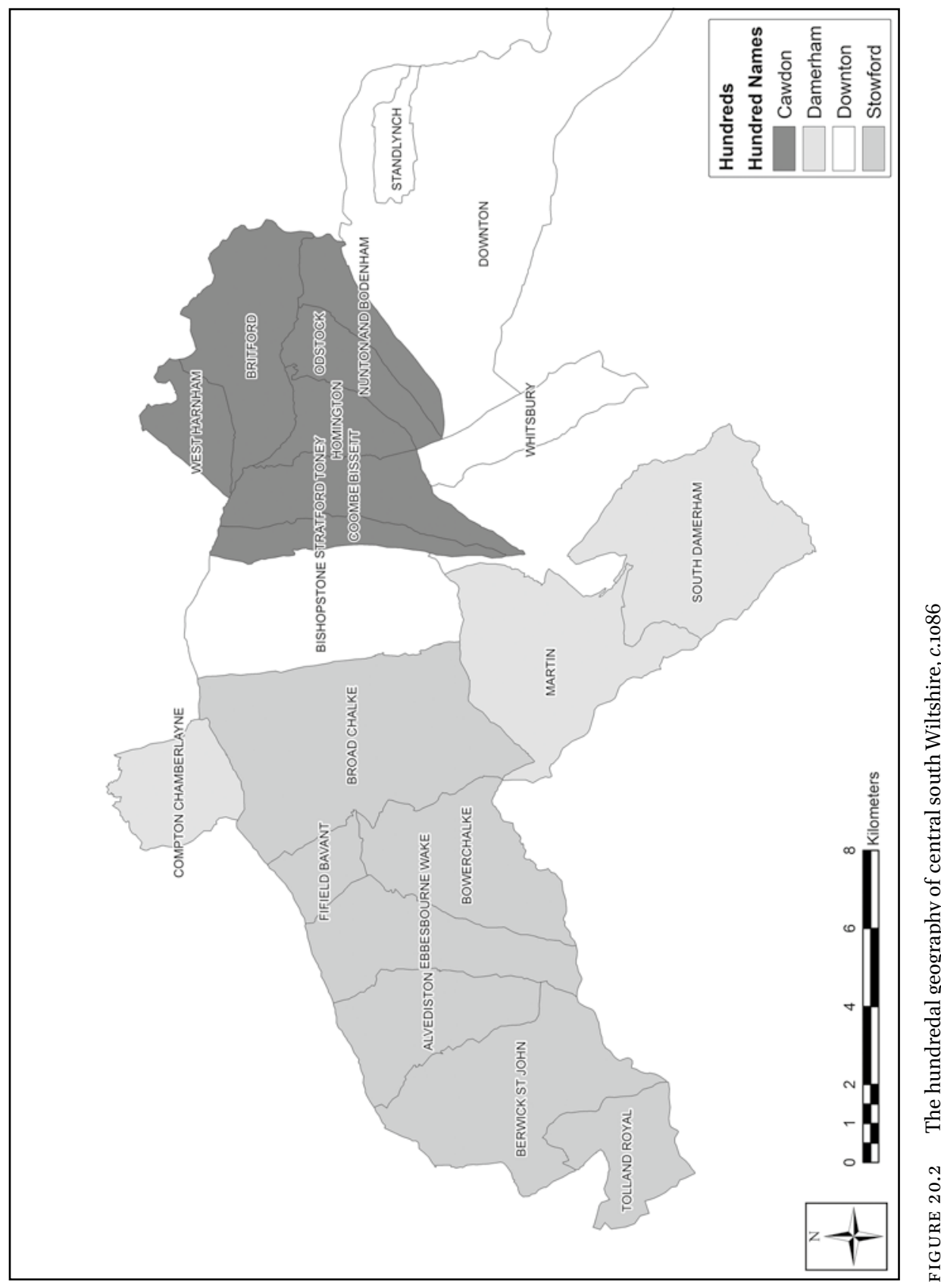


the rector of Broad Chalke presented to the vicarage of "his chapel of Bower Chalk". ${ }^{9}$ In 1394, his successor was responsible for providing a chaplain for Gurston: in 1317 there was a parson "of Broad Chalk and Gurston".10 In 1322, the rector of Broad Chalke was to present to a chantry which, initially in Knighton chapel, would be transferred to Chalke parish church. ${ }^{11}$ The earliest of these revealing documents is from 1312:

The aforementioned church [Broad Chalke] is prebendal [...] having four chapels annexed to it, namely Alvedeston', Bourchalk', Gerardeston' and Knynghteton, and all this from time out of mind $[\ldots]^{12}$

These documents suggest a large parish for Broad Chalke stretching along the Ebble valley as late as the 14th century, in turn suggesting that in the Saxon period it may have covered the entire hundred. ${ }^{13}$

The case of Damerham demonstrates another variation in the type and quality of evidence available for a particular church. The will of King Alfred contains an interesting reference to Damerham:

... it is my will that the community at Damerham be given their landbooks and their freedom to choose such lord as is dearest to them, for my sake and for Ælfflaed and for the friends for whom she used to intercede and I intercede. Moreover, a payment in livestock is to be made for the needs of my soul...14

The Register of Robert Hallum, Bishop of Salisbury 1407-17, ed. Joyce M. Horn, Canterbury and York Soc. 72 (York, 1982), p. 52; The Register of Roger Martival, Bishop of Salisbury 13151330, Canterbury and York Soc., 55-59, 4 vols. (Oxford etc., 1959-75), Vol. 1, ed. Kathleen Edwards, p. 230.

10 The Register of John Waltham, Bishop of Salisbury 1388-1395, ed. T.C.B. Timmins, Canterbury and York Soc. 80 (Woodbridge, 1994), p. 153; Register of Roger Martival, Vol. 3, ed. Susan Reynolds, pp. 34-55.

11 Register of Roger Martival, Vol. 1, pp. 401-06.

12 "Ecclesia eciam supradicta [Broad Chalke] prebendalis est et eciam [...] habens quatuor capellas sibi annexas, videlicet Alvedeston', Bourchalk', Gerardeston' et Knynghteton, et hec omnia a tempore cuius contrarii memoria non existit ...": Registrum Simonis de Gandavo, Diocesis Saresbiriensis, A.D. 1297-1315, ed. C.T. Flower and M.C.B. Dawes, Canterbury and York Society 40-41, 2 vols (Oxford, 1934), pp. 788-9o. The prebend mentioned was in Wilton Abbey.

13 Hundredal layouts on the maps are derived from the Thorn's work (see n.6), though parish boundaries are in nineteenth-century form.

14 " 7 ic wylle pæt man agyfe pam hiwum æt Domrahamme hyra landbec 7 hyra freols swylce hand to ceosenne swylce him leofast sy, for me 7 for Ælflæde 7 for pa frynd pe heo forepingode $\rceil$ ic forepingie. $7 \mathrm{sec}$ man eac on cwicum ceape ymbe minre sawle pearfe swa 
That a religious community of some kind existed at Damerham in the late gth century is the natural inference. Smyth concludes, on the basis of the inclusion of Ælfflaed, that the community was a nunnery. ${ }^{15}$ If he is right, Æfflaed was presumably the abbess, but this could imply a double monastery. Alternatively, a male community may have been provided with an abbess, even temporarily, to provide a woman of high status with employment and income, ${ }^{16}$ or Ælfflaed may even have been a secular figure. At any rate, the establishment can be called a mynster, and the tithing of the parish known as 'Munstrestret' may reflect something of what the locals would have called their church. ${ }^{17}$

The manor with the church came into the hands of Glastonbury Abbey and useful documents emanate from that institution. In a 13th-century manuscript survives a copy of a 12th-century account of Abbot Henry's acts noting that, finding six 'canons' there, he replaced them with a single chaplain, ${ }^{18}$ providing us in effect with a picture of the end of a mynster community: the document may reflect similar but unrecorded actions by his contemporaries or predecessors, an indication of one sudden mechanism by which many mynsters may have declined in status and function. Other sources allow suggestions to be made about the extent of Damerham's parish. In 1394, a document makes clear Tidpit's dependence on Damerham, for it was stated that the Rector of Tidpit was to bury his parishioners at Damerham. ${ }^{19}$ A charter of Bishop Walter of

hit beon mæge 7 swa hit eac gerysne sy 7 swa ge me forgyfan wyllan." S 1507. Quoted from Alfred the Great: Asser's Life of Alfred and Other Contemporary Sources, ed. and trans. Simon Keynes and Michael Lapidge (Harmondsworth, 1983), p. 178. Further comments in Blair, Church in Anglo-Saxon Society, pp. 303 and $325^{-26}$.

15 Alfred P. Smyth, King Alfred the Great (Oxford, 1995), p. 264. Lesley Abrams, Anglo-Saxon Glastonbury: Church and Endowment (Woodbridge, 1996), pp. 104-07 and 343, accepts the existence of a royal minster, with the gift to Glastonbury Abbey perhaps in part directed towards the reform of this community.

16 Suggested by Heighway, in Anglo-Saxon Gloucestershire, p. 111. Note that some apparently male mynsters had women attached, as seems to have been the case at Bedwyn, for example: Bern, Burgerbibliotek, MS 671, fol. $76 \mathrm{v}$, where a nun witnesses a manumission copied into a gospel book at Bedywn: translated by H.C. Brentnall, "Bedwyn in the Tenth Century," WANHM 52 (1947-48), 362-64.

17 E.H. Lane Poole, Damerham and Martin: A Study in Local History (Tisbury, 1976), p. 2. The tithings, including "Munstrstret," are listed in the early 16th-century Cartulary of Glastonbury Abbey, BL MS Harley 3961, fol. 149v.

18 "in manerio de Domerham ... inveni sex, qui dicebantur canonici, singulas prebendes possidentes": English Episcopal Acta, 8: Winchester 1070-1204, ed. M.J. Franklin (Oxford 1993), pp. 209-10. The original document is to be found copied into the early 14th-century Cartulary of Glastonbury Abbey, BL MS Add. 22934, fol. 12r.

19 Register of John Waltham, ed. Timmins, p. 154. This is in spite of the designations "esglise" and "ecclesie parochialis" in 1361 (at the presentation of a chaplain) in the abbot of Glastonbury's register: BL MS Arundel 2, fol. 55r. 
Salisbury of 1267 , and a vicarage ordination of 1270 , are strongly suggestive of the ecclesiastical dependence of Martin upon Damerham, ${ }^{20}$ which is significant, as Martin later acquired a parish of its own.

The fact that the surviving community in the 12th century was male may weaken the case for a nunnery at Damerham: a nunnery in Alfred's time cannot be ruled out, though, since the composition of communities could change, and it is worth noting that records, in the 12th and 13th centuries, of prebendaries at former mynsters do seem to correlate with nunneries: prebends were set up at Wilton, Romsey, Wherwell and Nunnaminster, Winchester and at the first three pastoral service for the surrounding area, as well as for the nuns, seems to have been a motive. ${ }^{21}$ Another possibility is that a defunct nunnery church and associated buildings were converted, perhaps in the 1oth century and possibly after the grant to Glastonbury, to serve as a mynster for the land thus received.

It should be noted that Damerham hundred, to which the mynster's parish seems to have been confined, included a detached portion at Compton Chamberlayne north of Stowford hundred, and yet there is no evidence to connect Compton with Damerham ecclesiastically. Speculative attachment to Damerham's parish has to rest on administrative practice which makes clear that a secular connnection was in operation in the later medieval period, for the inhabitants of Compton were expected to attend the hundred court at Damerham $c .1245 .{ }^{22}$ Suggestions of administrative and ecclesiastical intimacy are reinforced by the physical boundaries of parts of Damerham hundred, which follow the Roman road and Grim's Ditch in the north and Bokerley Dyke in the west. Parish and county boundaries still follow these features, and it has been suggested that Bokerley Dyke was in origin a negotiated frontier of the early Saxon period. ${ }^{23}$ The early origin of these boundary features, and the fact that they are followed by the apparent boundaries of Damerham hundred suggest that Damerham's parish never extended beyond the late 11th-century extent of the hundred.

Through Wiltshire a network of late Saxon hundred mynsters can be reconstructed with varying degrees of detail and confidence. Signs of early origin and status at these churches combine with later documentation of the breakup to varying degrees of their parishes, as at Broad Chalke and Damerham.

$20 \quad$ The Great Chartulary of Glastonbury, ed. Aelred Watkin, Somerset Record Society 59, 3 vols (Frome, 1947), 63 (1952), 64 (1956), 1:57-59.

21 For the Hampshire nunneries, Hase, "Development of the Parish," pp. 84-86 and 299-303. Barbara Yorke, Nunneries and the Anglo-Saxon Royal Houses (London, 2003), pp. 127-29, connects these prebends with the pastoral service of the attached parishes.

22 Great Chartulary of Glastonbury, 3:638-41.

23 Barbara Yorke, Wessex in the Early Middle Ages (London, 1995), pp. 23-24 and 85. 
So far as the mynsters' parishes can be reconstructed, correspondence with the hundredal layout around the time of Domesday Book appears significant. ${ }^{24}$ The repeated correspondence between parish and hundred invites speculation as to how it arose and it must be considered that it may have been the outcome of policy, or the by-product of royal use of the mynster network. ${ }^{25} \mathrm{~A}$ number of factors are likely to lie behind difficulties in some areas: the nature and quantity of the evidence and the vagaries of its survival; conversely, in some cases the number of sources makes the significance of each difficult to judge, or reveals genuine complications not revealed by the more straightforward pattern apparent elsewhere; a different political history in the north of the shire ${ }^{26}$ could have led to a different kind of pattern less easily or less clearly adapted, if at all, to match the network elsewhere, though it would be very difficult to prove this.

Further, the dominance of important religious communities such as at Malmesbury and, over the boundary with Somerset, Glastonbury, seems likely to have led to anomalies in the pattern insofar as their lands and churches were concerned, and to have been a significant factor in parish development. Outside Malmesbury's sphere, in the south of the shire, Old Minster, Winchester and Shaftesbury Abbey were among significant holders of lands and churches. Another of these was Wilton Abbey, which presided over lands where identification of mynsters and their parishes is difficult, possibly for the reasons outlined above. In this area the pattern of hundreds $c .1086$ was complicated (Fig. 20.3): the area included the main parts of the hundreds of Branchbury and Cadworth as well as detached portions of these and Warminster, Heytesbury and Damerham hundreds. Also, the sources are limited. Wilton Abbey produced a cartulary which includes 29 Anglo-Saxon charters relating to estates in Wiltshire, many of them in this area, but there is little information on churches and their relative status.

"Wiltshire grew out of Wilton," it has been declared, ${ }^{27}$ and whatever the exact identity of the people called the Wilscetan in $802,{ }^{28}$ Wiltshire must owe its name to the position of Wilton as a royal centre in the period when the shire took shape. Following the creation of the see of Ramsbury c.9og, the bishop

\footnotetext{
24 Pitt, "Wiltshire Minster Parochiae," pp. 23-96.

25 Blair, Church in Anglo-Saxon Society, esp. pp. 325-26: in the late 9th century "the royal administration had achieved territorial stability by battening onto minsters."

26 Briefly commented on in Pitt, "Wiltshire Minster Parochiae," pp. 13 and 114.

$27 \quad$ VCH Wilts 6, p. 7.

28 In The Anglo-Saxon Chronicle, trans. G.N. Garmonsway, 2nd ed. (London, 1972), pp. 58-59, the term is rendered as "the men of Wiltshire."
} 


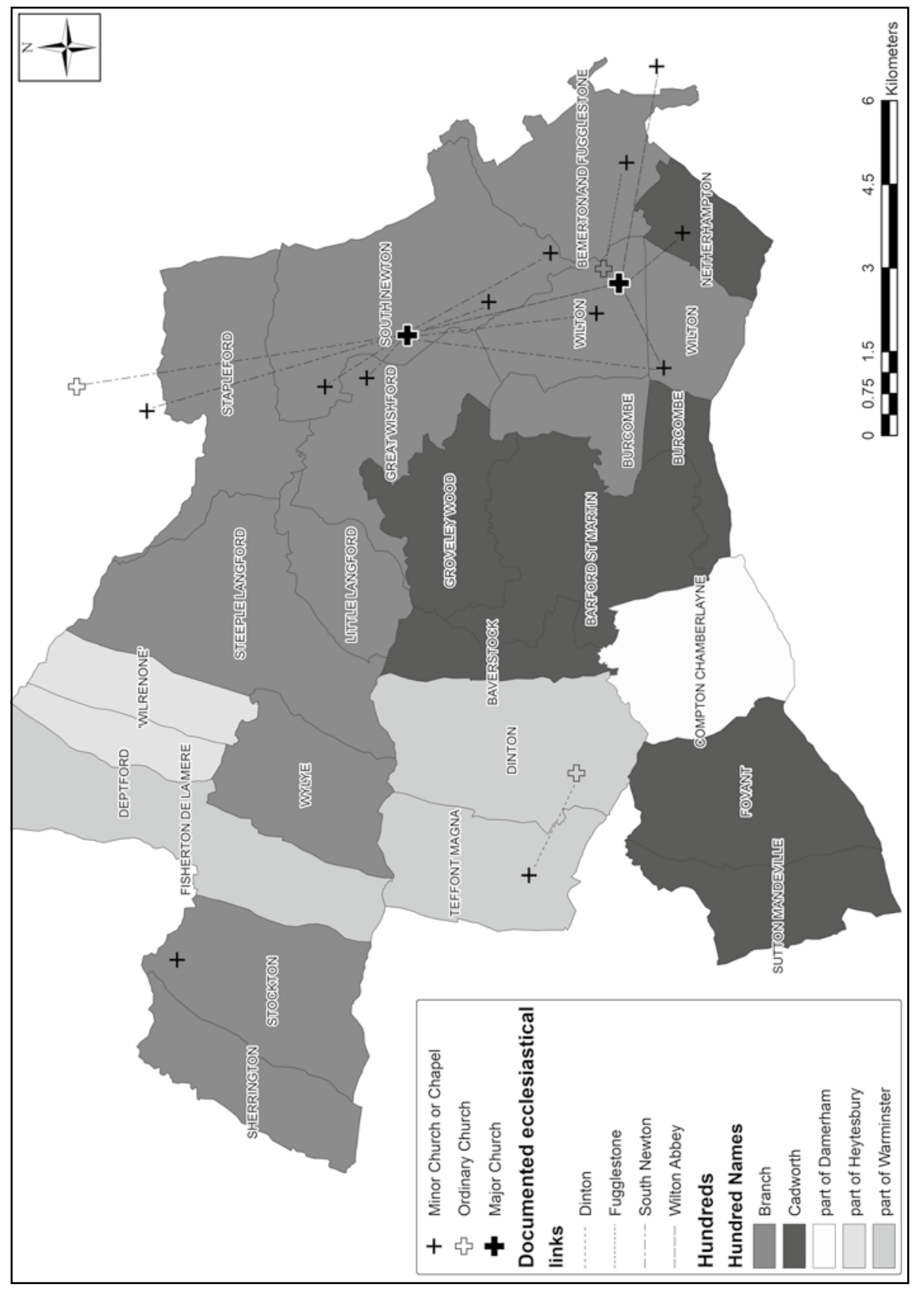

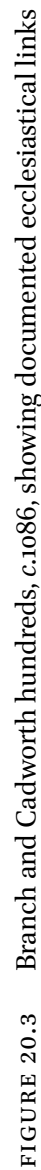


seems to have been thought of as the "bishop of Wiltshire."29 The nunnery founded in Wilton in the Saxon period was one of the more prestigious. Its existence is first known for certain in the 1oth century, ${ }^{30}$ although its own doubtful tradition, recounting the foundation of a church $c .800$, its conversion to a nunnery by King Egbert and his sister Alburga in 830 and rebuilding by King Alfred $c .890$, places the nunnery's foundation in the early 9 th century. ${ }^{31}$ Instead, foundation by Edward the Elder has been suggested: in the text of the 974 charter (S 799) Edgar states that his ancestor Edward founded the abbey, and although the charter is not thought genuine, this information is likely to have derived from the nunnery's own tradition. Doubts must remain in place concerning this tradition. ${ }^{32}$ It seems legitimate to wonder whether Alfred's actions were of more significance than those of the alleged founder of c.80o, Egbert, or Edward, ${ }^{33}$ but at different times the community may have wished to provide itself with a more appropriate history.

There is some evidence that the nunnery was reformed in the later 1oth century, and in connection with this, and the 15th-century account's claims of refoundation by Alfred, are the ideas that this late gth-century refoundation was connected with the provision of a mynster, separate from the nunnery, for the town, and that reform of the nunnery in the late 1oth century resulted in its move to a new site, separating it even more effectively from the proposed mynster. ${ }^{34}$ These suggestions rely on a picture of a female community being founded c.80o within a pre-existing mynster, moving later as it gained its own

29 Bishops Ælfstan, who died in 981, Ælfric, who became archbishop of Canterbury in 994 $\times 95$, and Beorhtwold, whose appointment is recorded 1006, are thus designated in ASC C 981, A 994, and CDE 1006. Beorhtwold was called both "episcopus Ramesberiensis" and "Wiltonensis episcopus" in the 12th century: Scott, Early History of Glastonbury, pp. 138-41.

30 The first surviving charter ( $\left.\mathrm{S}_{424}\right)$ to the nunnery is dated 933.

31 Simon Keynes, Anglo-Saxon Charters: Archives and Single Sheets, British Academy/Royal Historical Society Committee on Anglo-Saxon Charters (forthcoming), recounts the traditions recorded in the 15th century, and suggests that the poet had access to the Abbey's archive. Barbara Yorke, 'Sisters under the Skin?' Anglo-Saxon Nuns and Nunneries in Southern England," Reading Medieval Studies 15 (1989), 95-117. For comments on Goscelin, Edith and the character of the community, Susan J. Ridyard, The Royal Saints of AngloSaxon England: A Study in West Saxon and East Anglian Cults (Cambridge, 1988), pp. 140-54.

32 Yorke, Nunneries, pp. 75-76.

33 Alfred is known to have founded religious houses, in the context of attempting to revive spiritual life.

34 Jeremy Haslam, "The Towns of Wiltshire," in Anglo-Saxon Towns in Southern England, ed. Jeremy Haslam (Chichester 1984), pp. 87-147, at p. 123. Ridyard also finds indications in Goscelin's Vita Edithe that the Abbey was undergoing reform during her time: Royal 
identity, and therefore seem to rely on an acceptance of the traditions mentioned above.

Three possibilities suggest themselves and they are not mutually exclusive. One, that Wilton's nunnery was itself a mynster serving a parish in the Saxon period, for an important religious establishment in the town which gave its name to the shire might be expected to have been such a church: another, that a separate church in the town served this function; finally, that the area considered contained other churches whose origins were as Saxon mynsters. The nunnery did maintain a small number of priests in the later Saxon periodGoscelin, who wrote the Vita Edithe, was possibly one of them ${ }^{35}$ —and 'double minsters', with an attached community of male clergy, served the needs not just of the nuns but also of a parish. ${ }^{36}$ However, there is evidence concerning churches of close proximity to Wilton which makes it hard to suggest a large parish for any church in the borough itself. If St Mary's was a mynster, the evidence for this has largely vanished. The chapel of Netherhampton was apparently dependent upon St Mary's in 1394, but this is the only ecclesiastical link documented in later medieval times. ${ }^{37}$ The church became the town's mother church in the 16th century, following the falling into disuse of many of the town's other churches during the preceding two centuries, and this has been held to indicate this church's previous high status. ${ }^{38}$ Receipt thereafter of all the town's tithes and those of Burcombe, Bulbridge and Ditchampton ${ }^{39}$ may be no more than the natural result of these late changes.

Wilton's cartulary does contain one document which seems to suggest a mynster on its lands, at South Newton. In 1208 an agreement was reached regarding the advowson of a chapel at Great Wishford. The chapel was allowed to receive tithes of corn and of twenty acres held by its parson, but all tithes of Henry de Albeni's demesne were acknowledged to be a right of "Niwetune" church, which was already in receipt of a pension from Wishford chapel, and retained the right of presentation to it. ${ }^{40}$ Later, the "Inquisitions of the Ninth"

Saints, p. 141, n. 5. On reform in relation to the nunneries in particular, see Yorke, Nunneries, pp. 85-89.

35 And he mentions two others there in King Edgar's time: Ridyard, Royal Saints, p. 144; $V Æ d R$, pp. 94, 98 .

36 John Godfrey, "The Place of the Double Monastery in the Anglo-Saxon Minster System," in Famulus Christi: Essays in Commemoration of the Thirteenth Centenary of the Birth of the Venerable Bede, ed. Gerald Bonner (London, 1976), pp. 344-50.

37 Register of John Waltham, ed. Timmins, p. 145.

$38 \quad V C H$ Wilts 6, pp. 28-30. Haslam, "Towns of Wiltshire," p. 143, n. 53.

$39 \quad$ VCH Wilts 6, p. 30.

40 Registrum Wiltunense, ed. R.C. Hoare (London, 1827), pp. $16-17$. 
reveal that the parson of South Newton was entitled to the offerings made in "three chapels,"41 and several sources allow the identification of these chapels. One must have been Great Wishford, and in 1394 it was the rector of South Newton's responsibility that the windows of Little Wishford's chapel were not in good repair. ${ }^{42}$ Ugford, with a chapel perhaps by ${ }^{1191},{ }^{43}$ was in South Newton parish until the 2oth century, and both Ugford and Burden's Ball immediately to the north of Wilton were served from South Newton in $1535 .{ }^{44}$ Institution to the church of St Peter, Bulbridge, on the other side of Wilton to the south, was in 1248 in "Niwetone" church. 45

South Newton's church lacks the appearance of a church of former notable wealth and status, and the very name of the vill would seem to suggest relatively late origins. The nunnery seems to have played a role in the high status of this church, for it was attached to a prebend in Wilton Abbey. Its rights over nearby churches may result either from gift, by the abbess, ${ }^{46}$ or from her protection of the parochial rights South Newton's church acquired when founded, perhaps late in the Saxon period but before other nearby churches. The best explanation for the South Newton evidence may be that it is one of many churches which acquired rights late in the Saxon period and for a variety of reasons not necessarily connected with early foundation or earlier mynster status. Its attachment to one of the abbey's prebends would have funded that position-but 13th-to-16th-century evidence discussed above suggests it is quite legitimate to connect the church's status, and its prebendary, with an intention to provide for the pastoral service of its parish. ${ }^{47}$

The area in question contains several pieces of Anglo-Saxon sculptural work. The Wylye valley includes the church of Knook with a tympanum, in the past given a Saxon date by more than one writer, and perhaps a cross-shaft remnant, part of a cross shaft at Codford St Peter, a cross fragment found at Hanging Langford and a tympanum and rood at Little Langford. Most of these sculptural remains have been dated, rightly or wrongly, to the first half of the

41 Nonarum Inquisitiones in Curia Scaccarii temp. Regis Edwardi III, Record Commission (London, 1807), p. 177 .

42 Register of John Waltham, ed. Timmins, p. 146.

43 VCH Wilts 15, p. 225, and p. 214 (map).

44 Valor Ecclesiasticus, temp. Hen. VIII, ed. John Caley and Joseph Hunter, Record Commission, 6 vols (London, 1810-34), 2:100.

45 Charters and Documents illustrating the History of the Cathedral, City and Diocese of Salisbury, ed. W.H. Rich Jones and W.D. Macray, RS 97 (London, 1891), p. 313.

46 As documented later $c .1191$, when the abbess granted "decimae de dominico de Stokes, et viii solidi pro decimis de dominico nostro de Avena”: Charters and Documents, ed. Rich Jones and Macray, pp. 52-53.

Again see Yorke, Nunneries, pp. 127-29. 
9th century. ${ }^{48}$ Codford St Mary has been suggested also to incorporate Saxon remains in its structure, ${ }^{49}$ and Teffont Magna's church contains fragments of a Saxon cross-shaft. ${ }^{50}$ Other churches are known to have existed in the area in the late Saxon period: Burcombe, very close to Wilton, has a church incorporating late Saxon features, and at Bemerton a church was present by 968 when it was given with two hides to the nunnery: the charter ( $\left.\mathrm{S}{ }_{7} 67\right)$ mentions the previous holders Regenweard and Blithher, suggesting perhaps a proprietary church founded by one of these men or a predecessor. Although the church was given to the nunnery, it appears in later sources dependent not upon Wilton but upon Fugglestone-pastoral arrangements were evidently made either before that grant, or by the nunnery.

The cross-shafts raise the same interpretational problems as that at Broad Chalke: unlike Broad Chalke, these churches have no hint of superior status in later sources of any kind, including episcopal registers, and may be suggested to contain the remains of crosses dating from before the building of the churches. Meanwhile, tympana have been found in many lesser churches, and are likely to date from after the Norman Conquest (above, n. 48): leaving those aside, the churches at Knook, Codford St Peter, Codford St Mary, Hanging and Little Langford might have been founded comparatively early, and through this early foundation acquired independence earlier than most churches.

Examination of the charters for this region and the topography of the estates described in their bounds may support this suggestion: the Wylye valley was, it seems, divided into self-sufficient units, farming open-field systems, by the gth century, following a pattern of allocation of areas appendant to royal territory (in this case, the royal centre at Wilton). ${ }^{51}$ It might be natural for

48 P.G. Medd, "Anglo-Saxon Ecclesiastical Organisation in the Kingdom of Wessex," (Univ. of Oxford, B.Litt. thesis, 1958), p. 175. H.M. Taylor, however, dates Knook's tympanum to c.10oo: "Anglo-Saxon sculpture at Knook," WANHM 63 (1968), 54-57. See also H.M. and Joan Taylor, Anglo-Saxon Architecture, 3 vols (Cambridge, 1965-78), 1:364-65. G. Zarnecki, "1066 and Architectural Sculpture," Proceedings of the British Academy $5^{2}$ (1966), 87-104, esp. pp. 98-101, draws on regional and continental parallels to argue that the earliest tympana date from the late 11th century.

49 C.E. Ponting, "Notes on Churches in the Neighbourhood of Warminster," WANHM 27 (1894), 245-79. E.H. Goddard, "Notes on pre-Norman Sculptured Stones in Wiltshire," pp. 43-49 in the same volume, has some discussion of the other remains mentioned. On Codford St Peter, see also K.G. Forbes, "The Codford Saxon Carving," WANHM 62 (1967), 34-37.

5o VCH Wilts 8, p. 78 .

51 Della Hooke, "Regional Variation in Southern and Central England in the Anglo-Saxon Period and its Relationship to Land Units and Settlement," in Anglo-Saxon Settlements (Oxford, 1988), pp. 123-51, especially pp. 126-27 and 134-40. Also her The Landscape of Anglo-Saxon England (London, 1998), pp. 117 and 122. 
independent estates to acquire their own churches, also with some independence, at a comparatively early date. If alternatively they acquired preaching crosses at that time, it is not unreasonable to think churches later appeared on estates that had passed into the hands of Wilton Abbey, thus greatly reducing the chances of survival of any evidence placing them in an earlier mynster parish.

The case of the parish layout in Wilton Abbey's lands thus illustrates the importance of landholding in the pattern of mynster parishes we see in the sources. For example, some of the churches already mentioned might count as 'estate mynsters' as much as 'hundred mynsters'. At Downton for instance, the land was in the hands of the bishop of Winchester early in the 1oth century, in royal hands for most of the rest of that century, and then restored to the bishop. The manor was the same unit as the hundred and, I have suggested, the parish. ${ }^{52}$ One wonders therefore whether the extent of the parish is owed to the fact that bishop and king were able to preserve it from the effect of encroachments resulting from the foundation of lesser churches within it. At Damerham the situation was similar. The hundred and the manor held by Glastonbury Abbey were the same unit, passing to the abbey by the will of Æthelflaed in the late 1oth century. Detached parts of Damerham hundred, at Compton Chamberlayne, and of Downton hundred, at Bishopstone, were likely added in around this time for the administrative convenience of their landlords. Again, at Broad Chalke, the hundred mynster might be regarded as an estate mynster, the hundred as noted being granted to Wilton Abbey, during the 1oth century. At Tisbury, the mynster and 20 hides of land surrounding were granted to Shaftesbury Abbey, a gift which Æthelred II confirmed in 984, and the parish, which I have suggested encompassed a number of later parishes around Tisbury, corresponds closely to the bounds attached to the surviving charter. ${ }^{53}$

Undoubtedly gifts of lands to ecclesiastical institutions led to the creation of the records that allow us to look at the mynster parishes-though if Wilton Abbey created such records, they are lost. Additionally though, these institutions were prestigious and educated enough to defend, or establish, the rights of the churches on their lands, so that in turn their relatively large parishes survived long enough to be glimpsed in later records. The churches involved may have existed already, as mynsters or as lesser churches dependent on older mynsters, or they may have been newly founded shortly after the receipt of the

$5^{2} \quad$ Pitt, "Wiltshire Minster Parochiae," pp. 29-32.

53 Pitt, "Wiltshire Minster Parochiae," pp. 50-57. 
lands. If already extant, they may have acquired 'hundred mynster' status at that time, in cases in which hundred and estate were the same unit.

Concentrations of ecclesiastical estates may equally be responsible for evidence that is difficult to interpret. In Thornhill hundred in the north-east of the shire (Fig. 20.4), Aldbourne's church existed by the time of Domesday Book, with a priest holding two hides, and the land had in 1066 been in the hands of the Godwin family (Harold II's mother). ${ }^{54}$ If the hundred had a mynster it may have stood at Aldbourne. However, this cannot be certain due to the rights of other landlords in the hundred. At Wanborough a church existed by

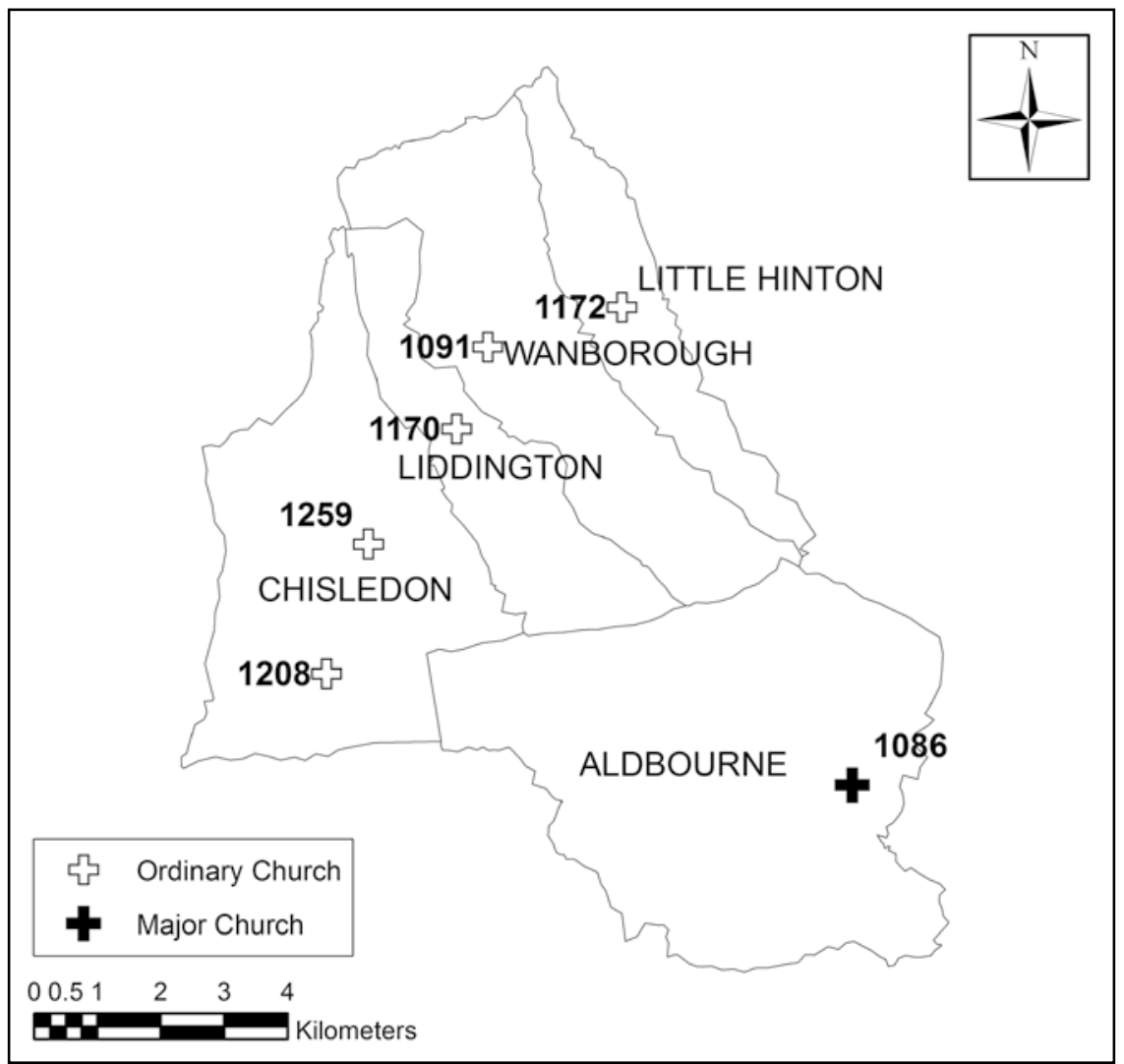

FIGURE 20.4 Thornhill hundred, $c .1086$, showing churches with dates of first known reference

54 GDB, fol. 65 r. 
1091, showing no evidence of dependence upon another, largely, it may be suspected, because it was in the hands of the bishop. ${ }^{55}$ The lands, however, had been granted in the 9th century to Old Minster, Winchester and included Little Hinton. ${ }^{56}$ Liddington, meanwhile, was a Shaftesbury Abbey estate by $1066 .{ }^{57}$ Chiseldon was among the estates of New Minster, Winchester, from early in the 1oth century ${ }^{58}$ and there may already have been a church. In short several religious institutions held lands, and churches which they may even have founded, in the hundred and they would no doubt have competed to promote the influence and status of churches on their estates-after all, income was involved - so that, if there was a hundred mynster here, it cannot be certain which church it was. If it had been Aldbourne, even the Godwins were unable to preserve its rights against the bishops and communities of Old and New Minsters, Ramsbury/Sarum, Shaftesbury and Glastonbury. 59

Other estate holders may have competed in Elstub hundred (Fig. 20.5), where a mynster stood at Netheravon, ${ }^{60}$ a late Saxon tower, once with structures on each side, now at the west of the more familiar nave and chancel. However, later evidence also suggests something more than a simple parish church, and pre-Conquest foundation, at Enford-lands here in the bishop of Winchester's hands in 1066 had very possibly come into the hands of Old Minster, Winchester, in the 1oth century. ${ }^{61}$ Considering that Netheravon was another estate of the powerful Godwin family, a link between that family and the surviving structure must be suspected. ${ }^{62}$ It could have been built as a manorial church

55 Vetus Registrum Sarisberiense alias dictum Registrum Sancti Osmundi Episcopi: The Register of S. Osmund, ed. W.H. Rich Jones, RS 78/1-2, 2 vols (London, 1883-84), 1:198-200. The Norman-period church seems to have been cruciform, perhaps reflecting high status: $\mathrm{VCH}$ Wilts 9, p. 183 .

56 Pitt, "Wiltshire Minster Parochiae," p. 92.

57 Cartulary of Shaftesbury Abbey, BL MS Harley 61, fol. 8or, mentions Liddington's church in a survey of the abbey's lands of the 1170s. The charter of King Edmund (S 459) granting ten hides at Liddington to one Adulf also survives in the cartulary, fols 9v-1or, dated 940, so the land, at least, may have come into the abbey's hands during the 1oth century.

$5^{8} \mathrm{~S}_{370} ; \mathrm{GDB}$, fol. $67 \mathrm{v}$.

59 Pitt, "Wiltshire Minster Parochiae," pp. 91-93. Glastonbury Abbey held Badbury, which in turn might not have remained dependent upon Chiseldon had a church been built.

6 Pitt, "Wiltshire Minster Parochiae," pp. 94-96. GDB, fol. 65r. The Register of John Chandler, Dean of Salisbury 1404-17, ed. T.C.B. Timmins, Wiltshire Record Society 39 (Devizes, 1984), pp. 30 [1405], 89 [1408], on West Chisenbury's dependence. $v C H$ Wilts 11, pp. 178-80.

61 Charters and Documents, pp. 366 [1291], 54 [Coombe, c.1194]; Select Documents of the English Lands of the Abbey of Bec, ed. Marjorie Chibnall, Camden 3rd ser. 73 (1951), p. 57 [Compton, c.1230?]. GDB, fol. 65v; Taxatio, p. 180.

62 Other churches associated with the family are mentioned in Blair, Church in Anglo-Saxon Society, pp. $357-58$. 


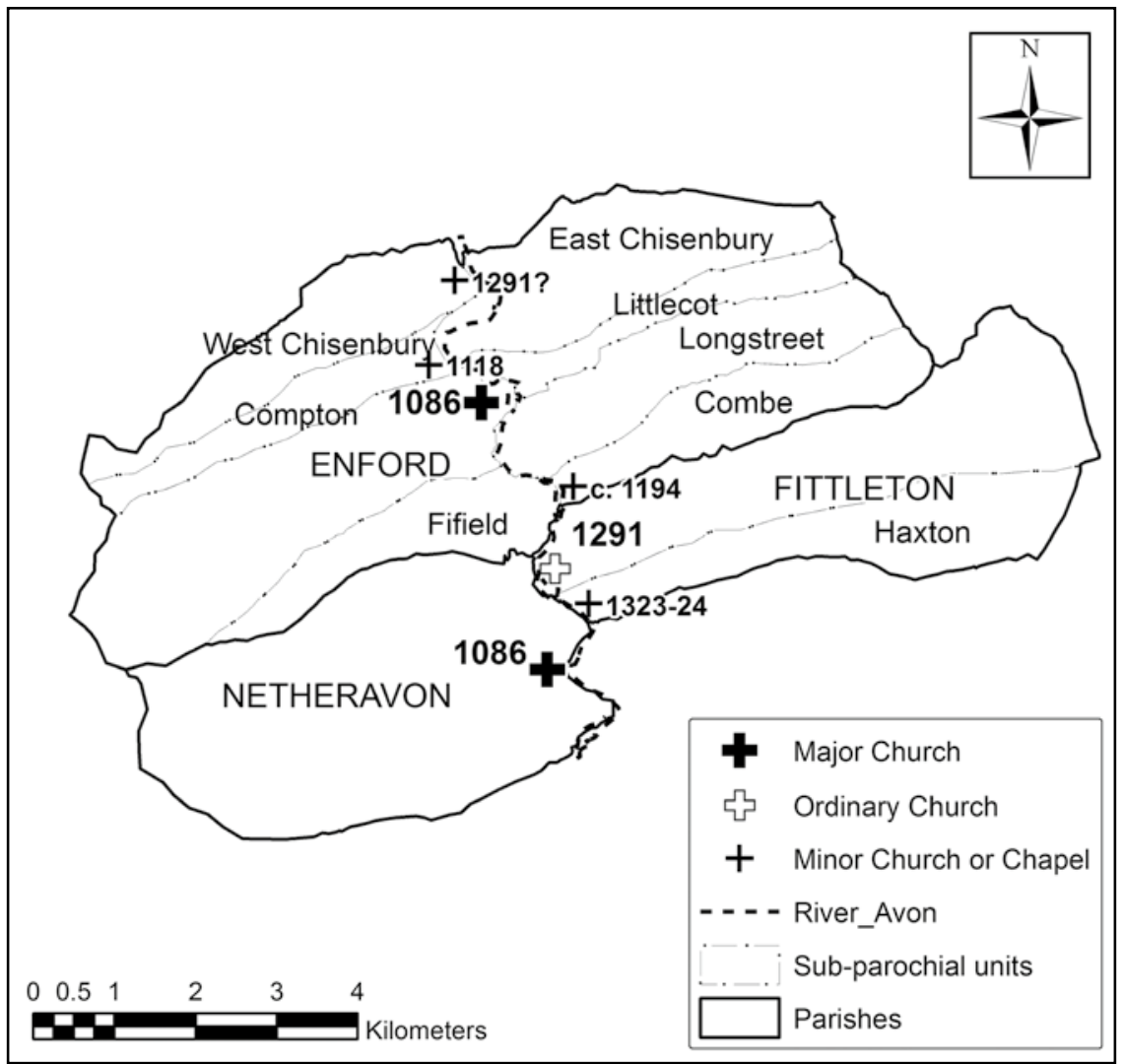

FIGURE 20.5 Elstub hundred, showing parishes and churches with dates of first known reference

for the family's estate, or as the church of a religious community, which chimes well its endowment in $1086,{ }^{63}$ or indeed a combination of both, and in either case possibly succeeding or perpetuating a hundred mynster. Or, the church of

63 "Nigel the Physician holds the church of this manor with 1 hide"; GD B, fol. 65r, listed under the king's lands, but three manors listed under Nigel's own section are stated to belong to the church of Netheravon. These were Stratton St Margaret (30 hides TRE), Chisenbury (8 hides TRE) and another hide in Netheravon; GDB, fol. 73r. A hide was a typical 1086 holding for a Wiltshire mynster: that the manors were an endowment made by the Godwins as part of a project for the church seems a reasonable suggestion. 
1086 being described as "waste" in Domesday Book, the 'late Saxon' tower may relate to its replacement. ${ }^{64}$ Enford, even if not originating as a hundred mynster, became in effect the church for the bishop of Winchester's estate. The fact that the hundred had not been divided before 1086 suggests the layout of ecclesiastical and secular units overlies earlier arrangements.

Thornhill and Elstub hundreds show examples of what can be viewed as another 'layer' of ecclesiastical organisation, churches of lesser status than mynsters but likely to have been founded comparatively early and to have enjoyed some local standing hinted at in the later sources. In the past I have tried to suggest that acquisition in the 1oth century, by religious establishments, especially those involved in the reform movement of the time, is likely to have been one reason for the desire that churches be founded on the lands involved, and corresponding parishes laid out. ${ }^{65}$ There were other changes in the period, however, including the proliferation of small secular estates, thought to have been one of the reasons behind the foundation of dependent churches, many of which only acquired parochial status much later, centuries later in some cases. Further, a very significant phenomenon - the appearance of nucleated villages replacing a previously much more scattered settlement pattern and associated with the laying-out of open-field systems - is generally thought to have begun in the 9 th century and continued through the late Saxon period. ${ }^{66}$ The effects on people's lives would have been profound, and one of those effects was surely to foster the sense of community we see in the later medieval period, and also, very likely, the sense that one of these new communities should have its own church, even if it remained subject to the local mynster long after its foundation.

Further research may help answer some of the remaining questions, including the nature and geography of pastoral provision in the area in the early Anglo-Saxon period. Meanwhile, the sources show, in my view, that AngloSaxon ecclesiastical organisation consisted of and grew into a 'layered' pattern: hundred mynsters perhaps lay at the centre of these layers, replacing or growing out of an older pattern. Nunneries appear to have established prebends, not necessarily based on existing mynsters: perhaps at Damerham only the

\footnotetext{
64 John Blair, pers. comm.

65 Pitt, "Malmesbury Abbey and Late Saxon Parochial Development"; "Minster Churches and Minster Territories." Hooke, Landscape of Anglo-Saxon England, p. 117.

66 See for example, Hooke, Landscape of Anglo-Saxon England, pp. $115 \mathrm{ff}$.
} 
prebendaries lasted beyond 1066, their existence beyond that of the nuns possibly suggestive of pastoral functions. In Wilton's case it can be suggested that there was a mynster, serving a unit at some point divided into Branchbury and Cadworth hundreds. Its connection with the late Saxon nunnery is difficult if not impossible to disentangle with the evidence available. The abbey's estate was the result of endowment intended to support the nunnery: whatever that house's connection with a pre-existing mynster, it made arrangements for local pastoral provision. A number of other churches existed, founded at different times for different purposes, by royal and other major and minor landholders as well as by religious houses. Between hundred mynsters and these other churches, the pattern of landholding shaped the pattern of parishes now discernible, which is a late Saxon pattern. ${ }^{67}$

67 I am grateful to Alex Langlands for re-drawing the maps for this chapter. Any further research will benefit from, and perhaps be unsuccessful without, the input of a genuine scholar such as Barbara Yorke. My own research was undertaken with the benefits of her advice, encouragement and understanding, her instinctive knowledge of when support was needed and, conversely, when it was best to leave me to "get on with it." Mistakes and misinterpretations are my own. 